\title{
FAILURE OF SCOPOLAMINE, PILOCARPINE OR PHENOXYBENZAMINE TO INFLUENCE THE RATE OF OVIDUCT SECRETION IN THE RABBIT
}

\author{
D. L. BLAGK AND L. V. GROWLEY \\ Laboratory for Reproductive Physiology, \\ Department of Veterinary and Animal Sciences, \\ University of Massachusetts, \\ Amherst, Massachusetts, U.S.A.
}

(Received 12th August 1969)

The innervation of the oviduct is primarily adrenergic although parasympathetic fibres may also be present (see Brundin (1965) for a review of the literature). While the neural control of the oviduct musculature has received much attention, little is known of the effect of the nervous system on the rate of formation or composition of oviduct fluid. Bishop (1956) reported that pilocarpine injections increased both the rate of oviduct fluid secretion and secretory pressure. He concluded from his experiments that pilocarpine stimulated fluid production by way of the cholinergic innervation of the oviduct. He further concluded that pilocarpine caused the release of secretory materials from the oviduct epithelium since oviduct fluid after pilocarpine was cloudy and contained cellular débris.

The aim of this experiment was to determine whether the rate of oviduct fluid production could be altered by injections of pharmacological agents known to affect the sympathetic and parasympathetic nervous system.

Eight adult, New Zealand rabbits (about $3 \mathrm{~kg}$ ) were prepared for continuous collection of oviduct secretions by the method described by Clewe \& Mastroianni (1960). The collection device was slightly modified by encasing the glass collecting coil in an aluminium cassette provided with a removable cover. Approximately $1 \frac{1}{2}$ weeks was allowed between surgery and the beginning of the study. During this time, oviduct fluid was withdrawn from the collection device each morning and evening and the volume of secretion recorded.

The experimental period for each drug was 5 days. Each day during the 5-day experimental period, four observations on secretion rate were made at 2-hr intervals. The drug to be studied was given only on the 3 rd day, 2 days being allowed between experimental periods.

The drugs used (in the order of their use) were scopolamine, pilocarpine and phenoxybenzamine. All drugs were dissolved in $0.9 \%$ sterile sodium chloride solution immediately before use and injected subcutaneously. Scopolamine $(100 \mathrm{mg} / \mathrm{ml})$ was administered at the rate of $120 \mathrm{mg}$ per animal every $2 \mathrm{hr}$ to give a total dose of $480 \mathrm{mg}$. One injection of pilocarpine $(1.0 \mathrm{mg}$ in $1.0 \mathrm{ml}$ 
$0.9 \% \mathrm{NaCl}$ ) and one injection of phenoxybenzamine (10 $\mathrm{mg}$ in $1.0 \mathrm{ml} 0.9 \%$ $\mathrm{NaCl})$ were given to each animal.

After the last observation of oviduct fluid volume on each day, the fluid was withdrawn, placed in sterile plastic test-tubes and frozen for future analysis; the volume of fluid secreted during the night was also recorded.

Data on the volume of secretion were subjected to analysis of variance for a factorial design.

TABLE 1

EFFECT OF SCOPOLAMINE, PILOGARPINE AND PHENOXYBENZAMINE ON OVIDUGT SECRETION IN THE RABBIT

\begin{tabular}{c|c|c|c}
\hline $\begin{array}{c}\text { Day of } \\
\text { experimental } \\
\text { period }\end{array}$ & \multicolumn{3}{|c}{ Oviduct secretion/8 $\mathrm{hr}(\mathrm{ml}$ secretion \pm S.E. $)$} \\
\cline { 2 - 4 } & Scopolamine & Pilocarpine & Phenoxybenzamine \\
\hline 1 & $0.35 \pm 0.20$ & $0.44 \pm 0 \cdot 18$ & $0.32 \pm 0.15$ \\
2 & $0.42 \pm 0.23$ & $0.39 \pm 0.14$ & $0.38 \pm 0.17$ \\
$3^{*}$ & $0.38 \pm 0.20$ & $0.33 \pm 0.20$ & $0.38 \pm 0.20$ \\
4 & $0.40 \pm 0.20$ & $0.39 \pm 0.16$ & $0.35 \pm 0.25$ \\
5 & $0.38 \pm 0.17$ & $0.48 \pm 0.14$ & $0.35 \pm 0.17$ \\
\hline
\end{tabular}

* Day of drug administration.

Oviduct secretion volume was not significantly influenced by any of the drugs used in this study (Table 1). The doses of scopolamine and phenoxybenzamine used were based on results obtained in oviduct motility studies in our laboratory (Longley, Black \& Currie, 1968a, b). At the level used, these drugs are effective in altering oviduct motility and effecting cardiovascular changes. The dose of pilocarpine was the same as that used by Bishop (1956) and was sufficiently great to stimulate salivation. The possibility that these animals were not under the influence of the drug is slight. Rather, it is more likely that stimulation or inhibition of the cholinergic component of the autonomic nervous system does not influence the rate of oviduct secretion. Blocking the alpha adrenergic receptors with phenoxybenzamine is equally ineffective in altering the rate of oviduct fluid secretion.

This work was supported by the United States Public Health Grant HD 00745.

\section{REFERENCES}

Bishop, D. (1956) Active secretion in the rabbit oviduct. Am. F. Physiol. 187, 347.

BRUndin, J. (1965) Distribution and function of adrenergic nerves in the rabbit Fallopian tube. Acta physiol. scand. 66, Suppl. 259, 1.

Glewe, T. \& MastrolanNi, L. (1960) A method for continuous volumetric collection of oviduct secretions. F. Reprod. Fert. 1, 146.

Longley, W. J., Black, D. L. \& Currie, G. N. (1968a) Oviduct circular muscle response to drugs related to the automomic nervous system. 7. Reprod. Fert. 17, 95.

LoNGley, W. J., BLACK, D. L. \& CuRRIE, G. N. (1968b) Ovarian hormone control of ovum transport in the rabbit as influenced by autonomic drugs. 7 . Reprod. Fert. 17, 579. 